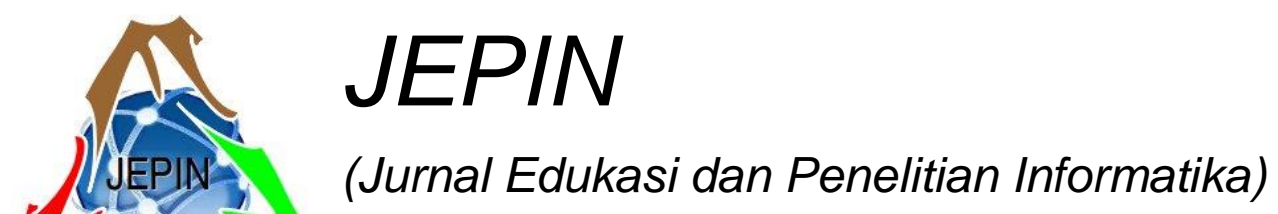

Vol. 6

No. 3

Desember

ISSN(e): 2548-9364 / ISSN(p) : 2460-0741

2020

\title{
Performance of Wind Power Plant in West Kalimantan, Indonesia
}

\author{
Firsta Zukhrufiana Setiawati ${ }^{\# 1}$, Rudi Kurnianto ${ }^{* 2}$, Bomo Wibowo Sanjaya*3, Rudy Gianto ${ }^{* 4}$, Seno Darmawan \\ Panjaitan ${ }^{* 5}$, Ananggirieza Nugraha ${ }^{+6}$ \\ * Climatological Station of Mempawah, Master Student in Electrical Engineering Untan \\ Jalan Raya Sungai Nipah, Mempawah, West Kalimantan, Indonesia \\ 1firstabmkg@gmail.com \\ ${ }^{\#}$ Department of Electrical Engineering \\ Jl. Prof. Dr. Hadari Nawawi, Pontianak, West Kalimantan, Indonesia \\ ${ }^{2}$ rudi.kurniantodee.untan.ac.id \\ 3bomo.wibowodee. untan.ac.id \\ ${ }^{4}$ seno.panjaitandee.untan.ac.id \\ ${ }^{5}$ rudy.giantodee.untan.ac.id \\ ${ }^{+}$Climatological Station of Sintang \\ Kapuas Kanan Hulu, Sintang, West Kalimantan, Indonesia \\ 6ananggirieza.nugraha@bmkg.go.id
}

\begin{abstract}
The aim of this paper is threefold. First, to calculate the correction factors based on existing meteorological station positions and its extension according to the basic map of West Kalimantan. Second, to reanalysis, the wind speeds from satellite measurements of national oceanic, and atmospheric administration (NOAA) and physical sciences division (PSD) in West Kalimantan by calculating its resultant and applying correction factor to create a map of wind power potential in West Kalimantan. Last, to apply the highest corrected wind speeds using HOMER simulation to know the wind energy potential. Conclusions have extracted the characteristics of wind speed variability over West Kalimantan, and HOMER simulation results of the highest wind speed.
\end{abstract}

Keywords - Normal meteorological standard, wind speed, reanalysis, wind power potential, HOMER simulation

\section{INTRODUCTION}

Based on the electric power system development plan of PT. PLN (Persero) [1] in West Kalimantan Province, as of September 2015 , over $89 \%$ of power supply in West Kalimantan came from oil-fired generators which would increase greenhouse gases. This issue is not in line with the government's efforts in the National Climate Change Mitigation Action Plan [2] which aims to reach a target of greenhouse gases by $26 \%$ in 2020 . According to the Directorate General of New Renewable Energy and Energy Conservation of the Ministry of Energy and Mineral Resources (Ditjen EBTKE) [3] on Indonesia Outlook Energy 2019, wind energy potential in Indonesia is $66.6 \mathrm{GW}$. Today, a wind power plant has been constructed in Sidrap, South Sulawesi and has operated since 2018 with a capacity of 75 MW. Sidrap wind power plant was the first and largest wind power plant in Indonesia. At the end of 2018, a wind power plant in Jeneponto, South Sulawesi has begun to operate with a capacity of $72 \mathrm{MW}$.

Many researchers had reported their studies about the potential of wind energy in Indonesia. However, it should be noted that the previous studies [4-6] used wind speed data in relatively narrow locations and short data length, and not using normal meteorological standards and reanalysis. For these reasons, the present study uses a long normal meteorological standard period of 1981-2010. This standard described events or property which the area experiences. Besides, the size of the research area extension and reanalysis are also used to get electric power potential spatially.

Therefore, this study is expected to offer a new idea for similar studies to produce a standard spatial distribution of electric power potential of wind energy. To find out in more detail, the potential of wind energy, a HOMER simulation has also been used, with the inputs of meteorological standard wind speed and wind power plant components. Essentially, the present study aims to combine electrical engineering with renewable energy and meteorology. It focuses on wind energy potential based on the normal meteorological standard of wind elements in West Kalimantan and its capability. 


\section{Methodology}

The research methodology was briefly drawn using the flowchart in Figure 1. The components of the flowchart are explained in detail in Section A-D.

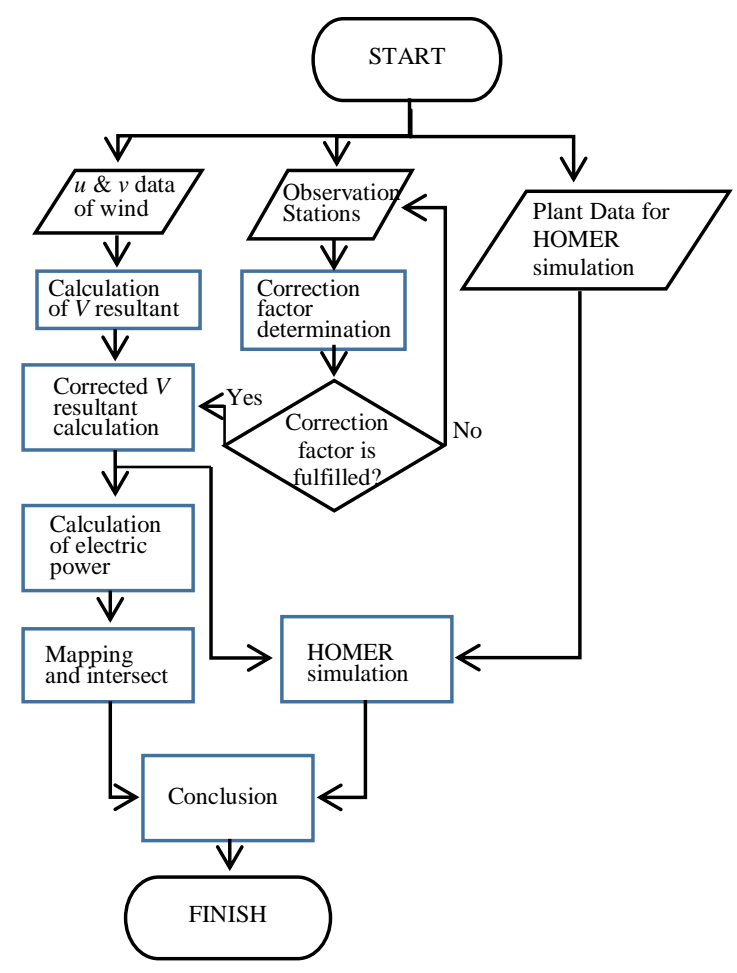

Figure 1 Research flowchart

\section{A. Calculation of Correction Factor}

In West Kalimantan, there are 8 meteorological station's positions. Since these stations are not enough to create a scatter map of wind power potential in West Kalimantan, it needed at least 25 grid positions with latitude and longitude covering all of the stations and surrounding waters. Determination of 25 grids is based on these station's positions, however, the position of the grid does not need to be the same as the station. The station and grid positions are listed in Table 1. When the grid positions are mapped into the West Kalimantan basic map, then the visual could be seen as Figure 2.

$Q G I S$ is used to create weighted spatial view maps distances or inverse distance weighting $(I D W)$. The data that is mapped is a calculation result of electrical power. $Q G I S$ uses the input of the SHP extention file for the base map of Kalimantan, West Kalimantan, and the sea around Kalimantan. QGIS is also used for the intersect process to determine the amount of electrical power in sub-districts in West Kalimantan.

The correction factor was determined by the IDW method. This is an interpolation method, to estimate the value of unsampled position from surrounding data, as formulated below [7].
TABLE I

MeteOROLOGICAL STATION AND GRID POSITIONS

\begin{tabular}{|c|c|c|c|c|c|c|}
\hline \multirow[t]{2}{*}{ No. } & \multirow{2}{*}{$\begin{array}{l}\text { Station } \\
\text { names }\end{array}$} & \multicolumn{2}{|c|}{ Positions } & \multirow{2}{*}{$\begin{array}{l}\text { Grid } \\
\text { No. }\end{array}$} & \multirow[t]{2}{*}{ Lon. } & \multirow[t]{2}{*}{ Lat. } \\
\hline & & Lon. & Lat. & & & \\
\hline 1 & $\begin{array}{l}\text { Supadio, } \\
\text { Pontianak }\end{array}$ & $\begin{array}{l}00^{0} \\
09^{\prime}\end{array}$ & $\begin{array}{l}109^{0} \\
24^{\prime}\end{array}$ & 1 & $5^{0}$ & $105^{0}$ \\
\hline 2 & $\begin{array}{l}\text { Susilo, } \\
\text { Sintang }\end{array}$ & $\begin{array}{l}00^{0} \\
03^{\prime}\end{array}$ & $\begin{array}{l}111^{0} \\
28\end{array}$ & 2 & $2.5^{0}$ & $105^{0}$ \\
\hline 3 & $\begin{array}{l}\text { Maritim, } \\
\text { Pontianak }\end{array}$ & $\begin{array}{l}00^{0} \\
01^{\prime}\end{array}$ & $\begin{array}{l}109^{0} \\
20^{\prime}\end{array}$ & 3 & $0^{0}$ & $105^{0}$ \\
\hline 4 & $\begin{array}{l}\text { Paloh, } \\
\text { Sambas }\end{array}$ & $\begin{array}{l}01^{0} \\
44^{\prime}\end{array}$ & $\begin{array}{l}109^{0} \\
19^{\prime}\end{array}$ & 4 & $-2.5^{0}$ & $105^{0}$ \\
\hline 5 & Mempawah & $\begin{array}{l}00^{0} \\
04^{\prime}\end{array}$ & $\begin{array}{l}109^{0} \\
11\end{array}$ & 5 & $-5^{0}$ & $105^{0}$ \\
\hline 6 & Nangapinoh & $\begin{array}{l}00^{0} \\
21^{\prime}\end{array}$ & $\begin{array}{l}111^{0} \\
45^{\prime}\end{array}$ & 6 & $5^{0}$ & $107.5^{0}$ \\
\hline 7 & $\begin{array}{l}\text { Rahadi } \\
\text { Oesman, } \\
\text { Ketapang }\end{array}$ & $\begin{array}{l}01^{0} \\
49^{\prime}\end{array}$ & $\begin{array}{l}109^{0} \\
57^{\prime}\end{array}$ & 7 & $2.5^{0}$ & $107.5^{0}$ \\
\hline 8 & $\begin{array}{l}\text { Pangsuma, } \\
\text { Kapuas } \\
\text { Hulu }\end{array}$ & $\begin{array}{l}00^{0} \\
50^{\prime}\end{array}$ & $\begin{array}{l}112^{0} \\
56^{\prime}\end{array}$ & 8 & $0^{0}$ & $107.5^{0}$ \\
\hline & & & & 9 & $-2.5^{0}$ & $107.5^{0}$ \\
\hline & & & & 10 & $-5^{0}$ & $107.5^{0}$ \\
\hline & & & & 11 & $5^{0}$ & $110^{0}$ \\
\hline & & & & 12 & $2.5^{0}$ & $110^{0}$ \\
\hline & & & & 13 & $0^{0}$ & $110^{0}$ \\
\hline & & & & 14 & $-2.5^{0}$ & $110^{0}$ \\
\hline & & & & 15 & $-5^{0}$ & $110^{0}$ \\
\hline & & & & 16 & $5^{0}$ & $112.5^{0}$ \\
\hline & & & & 17 & $2.5^{0}$ & $112.5^{0}$ \\
\hline & & & & 18 & $0^{0}$ & $112.5^{0}$ \\
\hline & & & & 19 & $-2.5^{0}$ & $112.5^{0}$ \\
\hline & & & & 20 & $-5^{0}$ & $112.5^{0}$ \\
\hline & & & & 21 & $5^{0}$ & $115^{0}$ \\
\hline & & & & 22 & $2.5^{0}$ & $115^{0}$ \\
\hline & & & & 23 & $0^{0}$ & $115^{0}$ \\
\hline & & & & 24 & $-2.5^{0}$ & $115^{0}$ \\
\hline & & & & 25 & $-5^{0}$ & $115^{0}$ \\
\hline
\end{tabular}

$$
Z_{p}=\frac{\sum_{i=1}^{n}\left(\frac{x_{i}}{d_{i}^{p}}\right)}{\sum_{i=1}^{n}\left(\frac{1}{d_{i}^{p}}\right)}
$$

where $Z_{p}=$ the data value to be estimated, $Z_{i}=\mathrm{i}^{\text {th }}$ data value,

$d_{i}^{p}=\mathrm{i}^{\text {th }}$ distance at series value $p$.

The formula is applied for every grid position and finally counts the average correction factor. 


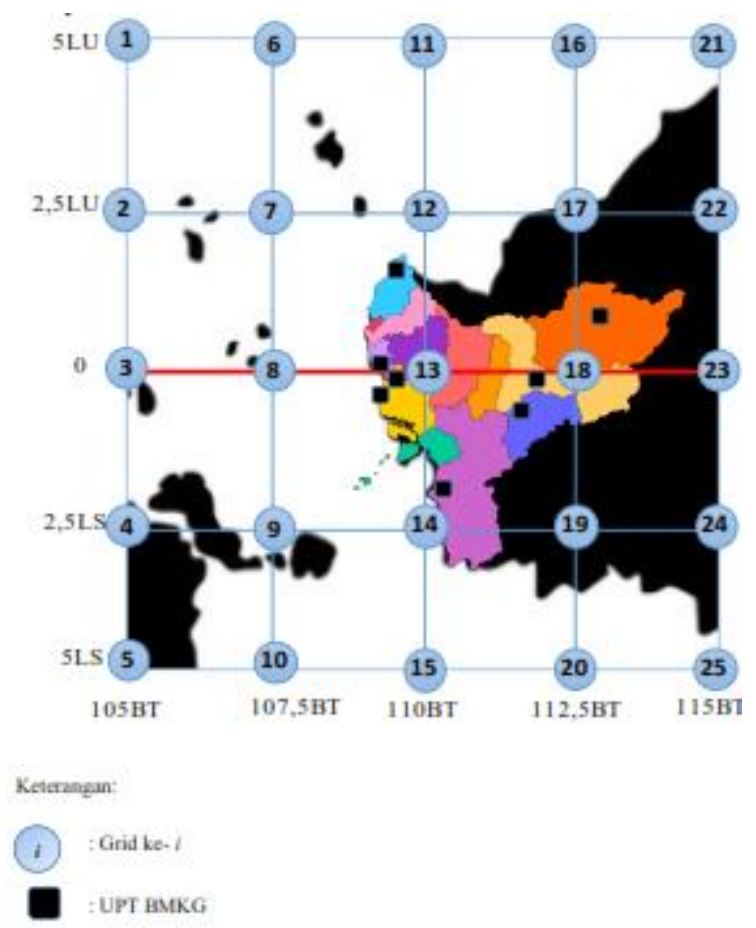

Figure 2 Position of grids on the basic map of the West Kalimantan

\section{B. Reanalysis}

WMO (the world meteorological organization) Guideline on the calculation of climate normal [8] points out that normal meteorological standard is the average of meteorological data computed for the following consecutive period of 30 years: 1 January $1981-31$ December 2010, 1 January 1991 - 31 December 2020, and so forth.

Based on technical regulation of the WMO Guideline on the calculation of climate normal [8], the normal meteorological standard is updated every ten years, where the first year of the period ends with 1 and the last yearend with 0 . The normal meteorological standard is used for two main objectives, i.e. as a benchmark for the latest or current observation to compare and as a basis for climate anomaly. The normal meteorological standard is also used implicitly and explicitly as a description of the most likely condition in an area.

WMO-TD/No.341 [9] also describes the calculation of the normal meteorological standard. The monthly standard normal is calculated from year-month values. For example, to calculate the normal meteorological standard of January, the averages of Januarys are calculated consecutively (January 1981, 1982, 1983,... 2010). However, if there is any missing data, a normal meteorological standard can not be calculated.

In this study, reanalysis data were NOAA and PSD outputs from Satellite measurements at $10 \mathrm{~m}$ above the ground and with an air pressure of 1,000 millibars. The data measured were zonal $(u)$ and traditional $(v)$ winds that performed sub-daily or every 6-12 hours, between 1981 and 2010 for all 25 grids.
- Calculation of Wind Speed Resultant

The wind speed resultant $(V)$ was determined from wind speed $u$, and $v$, according to equation (2) and Figure 3 below [10].

$$
V=\sqrt{u^{2}+v^{2}}
$$

where $u=$ Zonal wind $(\mathrm{m} / \mathrm{s}) ; v=$ traditional wind $(\mathrm{m} / \mathrm{s})$.

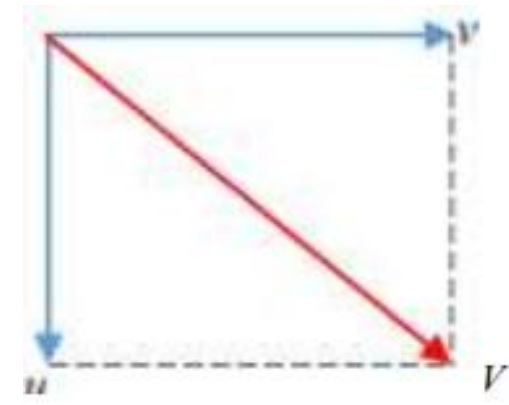

Figure 3 Illustration of wind speed resultant $V$

- Calculation of Corrected Wind Speed Resultant Correction value application was used on data reanalysis by multiplying average correction factor value with wind speed resultant of data reanalysis, as has been performed by Chauhan [11].

\section{Wind Power Calculation}

Brown, C.K., and Warne [12] stated that the wind energy conversion system to generate electric power is calculated by the equation below.

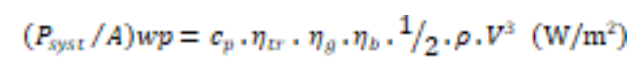

Where:

$\left(P_{\text {syst }} / A\right) w p=$ electric power generated per cross section unit of the blade; $c_{p}=$ coefficient of power $(0.4) ; \eta_{t r}=$ transmission efficiency $(0.95) ; \eta_{g}=$ generator efficiency (0.85); $\eta_{b}=$ battery efficiency $(0.75) ; \rho=$ air density $\left(1.2 \mathrm{~kg} / \mathrm{m}^{3}\right) ; V=$ corrected wind speed resultant $(\mathrm{m} / \mathrm{s})$.

Electric power calculation results were mapped using QGIS per monthly normal period and were intercepted. The intercept is an overlay analysis method, with the operation of cutting an input layer with an overlay attribute to produce and output with attributes that have data from the two attributes. The overlay is the ability to combine two attributes in one map. The process is illustrated in the following Figure [7]. 


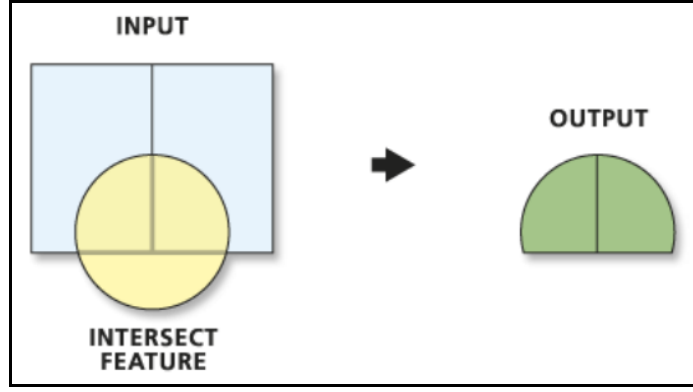

Figure 4 Illustration of intercept process in $Q G I S$

\section{HOMER Simulation}

HOMER simulation was used using inputs of corrected wind speed resultant data, load profile data, wind turbine (specification and prices), battery, and converter to result in the highest and the lowest electric energy as the potential of wind power in West Kalimantan.

\section{RESULTS AND DISCUSSION}

\section{A. Correction Factor}

Figure 5 shows that the highest correction factor is grid 21 , then the second-highest is grid 11 . Grid 21 is located at $5^{0} \mathrm{NL} 115^{0} \mathrm{EL}$, while grid 11 at $5^{0} \mathrm{NL} 110^{\circ} \mathrm{EL}$. Both are located at the same latitude which is $5^{0}$, which is the farthest location from the 25 grids.

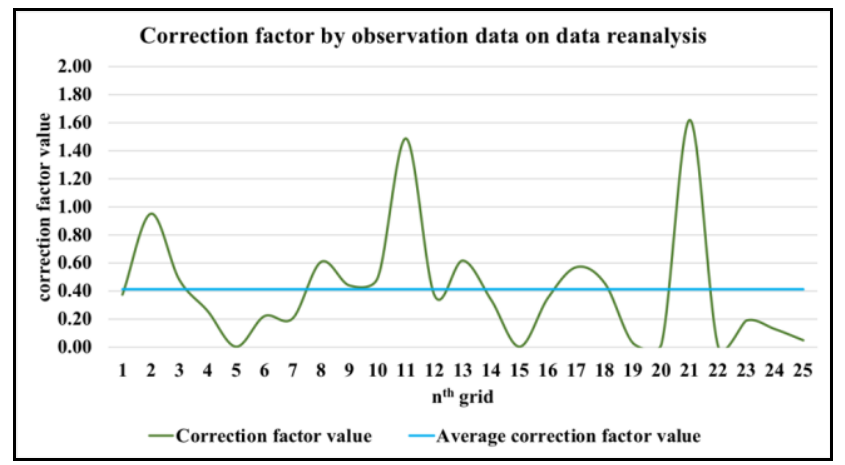

Figure 5 Correction factor by observation data on data reanalysis

The average correction factor was 0.41 (-- line). Ten grids had above and below average correction factors. It happened because most of the grids were located in the sea and some were located inland with a higher elevation than the surrounding areas. As stated in the previous paper [13], the correction value was affected by location. The higher correction was found with higher elevation. Similarly, the sea had rather significant data correction. This condition supported the importance of the correction factor in data reanalysis. Therefore, data reanalysis became more reliable for the next process, i.e. power calculation.

\section{B. Normal Climatological Standard (NCS) of Wind}

The use of normal climatological standards has 2 (two) main objectives, namely the first as a benchmark against the latest or current observations to be compared as a basis for climate anomaly analysis. Second, the normal climatological standard is also used implicitly and explicitly as a description of the conditions most likely to occur in a region. Therefore, the calculation of electric power using the normal climatological standard wind speed data is expected to be used as a standard reference regarding the potential for electrical power from wind energy inside the West Kalimantan region.

The wind is a mass of air that moves due to a gradient air pressure, therefore it becomes significant for understanding wind patterns and wind speed based on normal climatological standards [14]. The obtained normal climatological standard wind pattern as well wind speed is described as follows.

- Wind Patterns

In atmospheric science (meteorology), wind pattern is commonly defined as Streamline. Streamline analysis is performed for many reasons. Air Force Weather Qualification Training Packaged [14] stated that Streamline analysis was performed to identify wind patterns or character which passes a certain region.

In this study, analysis of Streamlines is performed to identify the pattern or characters of wind through West Kalimantan to determine the effects on the resulting electric power. Here's a Streamline analysis or normal climatological standard wind pattern.

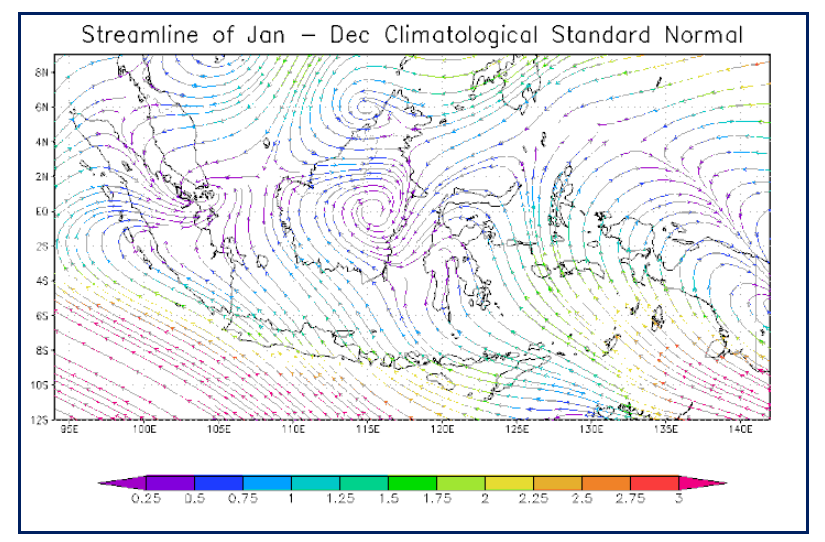

Figure 6 Streamline of January - December period

Figure 6 showed that the Streamline pattern entering West Kalimantan tended to be quiet or approaching $0 \mathrm{~m} / \mathrm{s}(0-1$ $\mathrm{m} / \mathrm{s}$ ). There was a Shear line (wind turn) and Eddy (closed vortex) characterized by reduced wind speed when passing certain areas. They are often perceived as the cause of bad weather. In terms of wind power, relatively low wind speed results in low wind power potential in West Kalimantan. Wind power will be made per month based on the normal meteorological standard.

- Wind Speeds

In Table 2, it is explained that several 6 grids (24\%) have a value of wind speed (normal climatological standard) before the correction was lower and smaller 
variability than after correction. Then, as many as 19 grids $(76 \%)$ have a lower wind speed value and small variability after the correction process. This shows that the correction process was successful, as evidence by $76 \%$ of the grid has small variability at the time after correction.

\section{Electric Power based on NCS of Wind Speed}

Based on the map of wind power potential that was calculated based on the NCS wind speed from January to December, there was the same distribution pattern. The central part of West Kalimantan was reported to have lower wind power potential than the northern and southern areas (the combined map is shown in Figure 7).

TABLE II

ANALYSIS RESULT OF NCS OF WIND SPEED

\begin{tabular}{|c|c|c|c|l|}
\hline $\begin{array}{c}\text { Grid } \\
\text { nr. }\end{array}$ & $\begin{array}{c}\text { Lon } \\
(\mathbf{d e g})\end{array}$ & $\begin{array}{c}\text { Lat } \\
(\mathbf{d e g})\end{array}$ & $\begin{array}{c}\text { Avg. } \\
\text { Gradient } \\
(\boldsymbol{m} / \mathbf{s})\end{array}$ & Graph pattern \\
\hline 1 & 5 & 105 & 5.87 & Before correction $>$ after correction \\
\hline 2 & 2.5 & 105 & 3.04 & Before correction $>$ after correction \\
\hline 3 & 0 & 105 & 3.30 & Before correction $>$ after correction \\
\hline 4 & -2.5 & 105 & 2.54 & Before correction $>$ after correction \\
\hline 5 & -5 & 105 & 2.38 & Before correction $>$ after correction \\
\hline 6 & 5 & 107.5 & 8.72 & Before correction $>$ after correction \\
\hline 7 & 2.5 & 107.5 & 6.55 & Before correction $>$ after correction \\
\hline 8 & 0 & 107.5 & 2.78 & Before correction $>$ after correction \\
\hline 9 & -2.5 & 107.5 & 2.05 & Before correction $>$ after correction \\
\hline 10 & -5 & 107.5 & 1.75 & Before correction $<$ after correction \\
\hline 11 & 5 & 110 & 1.31 & Before correction $<$ after correction \\
\hline 12 & 2.5 & 110 & 2.02 & Before correction $<$ after correction \\
\hline 13 & 0 & 110 & 0.96 & Before correction $<$ after correction \\
\hline 14 & -2.5 & 110 & 4.94 & Before correction $<$ after correction \\
\hline 15 & -5 & 110 & 3.31 & Before correction $>$ after correction \\
\hline 16 & 5 & 112.5 & 3.29 & Before correction $>$ after correction \\
\hline 17 & 2.5 & 112.5 & 0.85 & Before correction $>$ after correction \\
\hline 18 & 0 & 112.5 & 0.54 & Before correction $>$ after correction \\
\hline 19 & -2.5 & 112.5 & 1.65 & Before correction $>$ after correction \\
\hline 20 & -5 & 112.5 & 3.02 & Before correction $>$ after correction \\
\hline 21 & 5 & 115 & 0.49 & Before correction $<$ after correction \\
\hline 22 & 2.5 & 115 & 0.54 & Before correction $>$ after correction \\
\hline 23 & 0 & 115 & 0.69 & Before correction $>$ after correction \\
\hline 24 & -2.5 & 115 & 0.94 & Before correction $>$ after correction \\
\hline 25 & -5 & 115 & 2.78 & Before correction $>$ after correction \\
\hline & & & & \\
\hline
\end{tabular}

The condition was related to wind pattern or Streamline analyzed before where the central part of West Kalimantan had wind turn (shear line) and reduced speed to $<2 \mathrm{~m} / \mathrm{s}$. Wind energy in northern and southern areas tended to be bigger. It indicates wind pattern enters or exits West Kalimantan, so the resulting power is bigger because the wind speed is higher.

\section{Results of HOMER Simulation}

HOMER simulation selected the domestic load to be observed for 7 days. The daily profile is shown in Figure 8 . The observed daily load showed a clear peak load pattern at 04.00-08.00 a.m. and 05.00-10.00 p.m.

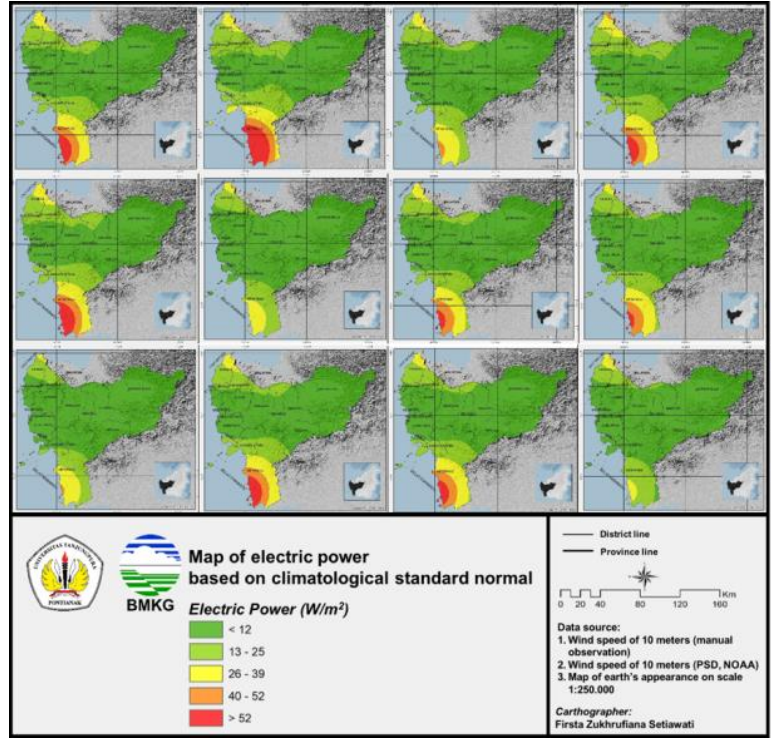

Figure 7 Map of Potential Power based on NCS

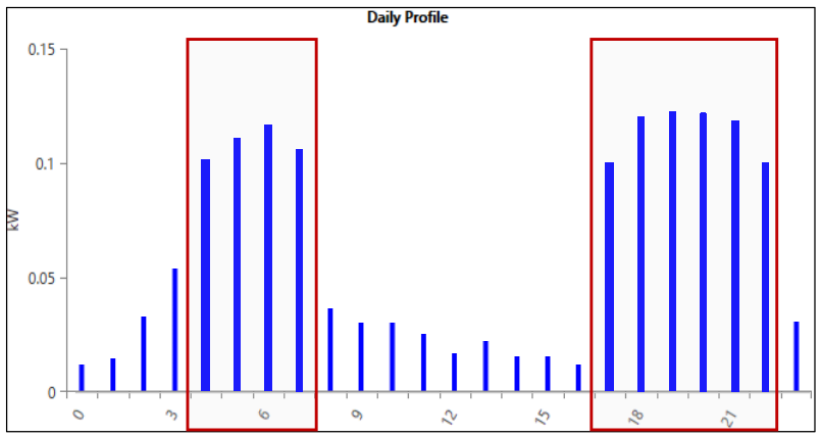

Figure 8 Daily load profile

This average wind speed was the NCS of wind speed in the selected simulation location i.e. Tumbang Titi. The highest average wind speed was $7.660 \mathrm{~m} / \mathrm{s}$ which occur in April, with an annual average of $7.07 \mathrm{~m} / \mathrm{s}$, as shown in Figure 9.

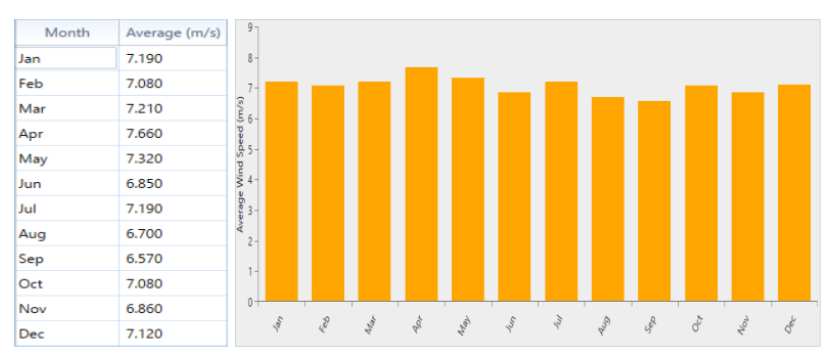

Figure 9 Monthly average wind speed

The annual average is suitable for the wind turbine Generic $3 \mathrm{~kW}$ or G3 based on the power curve (Figure 10), the minimum wind speed to produce power was $4.00 \mathrm{~m} / \mathrm{s}$. 


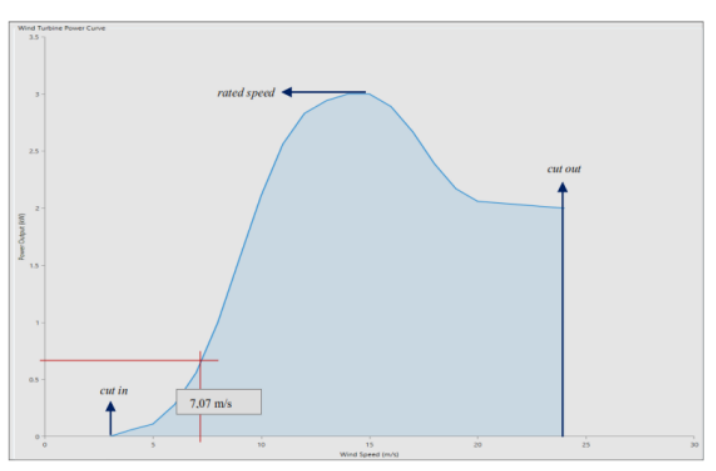

Figure 10 Typical power curve for G3 turbine

By the annual average wind speed of $7.07 \mathrm{~m} / \mathrm{s}$, the $\mathrm{G} 3$ could produce around $0.56-1 \mathrm{~kW}$. Meanwhile, Generic 10 $\mathrm{kW}$ or G10 could produce $2-3 \mathrm{~kW}$. On the power curve, both areas were still far from the maximum wind speed of $15 \mathrm{~m} / \mathrm{s}$ as a measure of wind speed maximum with each wind turbine.

The simulation in the present study used modeling (Figure 11). The specification of components of turbines and the simulation results are illustrated in Table 3 .

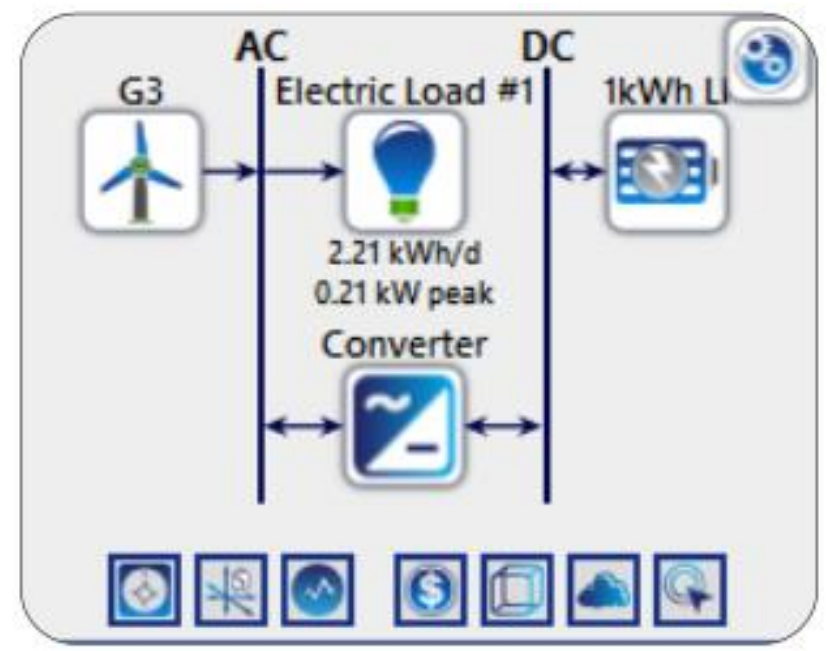

Figure 11 Typical HOMER simulation modelling for G3 turbine

In the G3 turbine simulation, according to each flow system, the equipment will be replaced in the $10^{\text {th }}, 15^{\text {th }}$, and $20^{\text {th }}$ years. In the G10 turbine simulation, the equipment will be replaced in the $15^{\text {th }}$ and $20^{\text {th }}$ years. Those wind power plants will obtain profit (remaining value in the power system component at the end of the project period) in the $25^{\text {th }}$ year.

The power generated by the G10 was only 4 times greater than the G3. This data can be used as a very meaningful consideration since it is less efficient to use the G10 wind turbine on the small scale. According to each flow summary, wind turbine requires the highest cost. Based on monthly average production (Figure 12), the G3 turbine produced the monthly average electricity production of $9,457 \mathrm{kWh} /$ year. The main load (primary load) has been fulfilled at $808 \mathrm{kWh} /$ year and has excess power of $8,613 \mathrm{kWh} /$ year. Meanwhile, if using a G10 wind turbine, it can produce $33,892 \mathrm{kWh} /$ year of electricity, the primary load has been fulfilled at 808 $\mathrm{kWh} /$ year and has excess power of 33,059 kWh/year.

\section{TABLE III}

SPECIFICATION OF COMPONENTS AND SIMULATION RESULTS

\begin{tabular}{|c|c|c|c|}
\hline Parameter & Type & Value & Results \\
\hline Battery & $\begin{array}{l}\text { Li-lon } \\
\text { Generic }\end{array}$ & $1 \mathrm{kWh} ; 6 \mathrm{~V}$ & $\begin{array}{l}\text { G3: the smallest initial SOC in April and May ( } 20 \% \\
\text { and } 25 \%) \text {. Generally, SOC of battery is } 82 \%-100 \% \text {. } \\
\text { G10: the smallest initial SOC in July ( } 30 \%) \text {. Generally, } \\
\text { soC of battery is } 85 \%-100 \% \text {. }\end{array}$ \\
\hline \multirow[t]{2}{*}{$\begin{array}{l}\text { Wind turbine } \\
\text { generator }\end{array}$} & G3 & $\begin{array}{l}\text { Rotor diameter: } 4.5 \mathrm{~m} \\
\text { Cut in speed: } 4 \mathrm{~m} / \mathrm{s} \\
\text { Maximum output: } 3 \\
\mathrm{kWh} \text { (at } 15 \mathrm{~m} / \mathrm{s} \text { ) }\end{array}$ & $\begin{array}{l}\text { G3: 9,457 kWh/year of electricity. The primary load: } \\
\text { 808 kWh/year; excess: 8,613 kWh/year. }\end{array}$ \\
\hline & G10 & $\begin{array}{l}\text { Rotor diameter: } 15 \mathrm{~m} \\
\text { Cut in speed: } 4 \mathrm{~m} / \mathrm{s} \\
\text { Maximum output: } 10 \\
\text { kWh (at } 15 \mathrm{~m} / \mathrm{s} \text { ) }\end{array}$ & $\begin{array}{l}\text { G10: } 33,892 \mathrm{kWh} / \text { year of electricity. The primary } \\
\text { load: } 808 \mathrm{kWh} / \text { year; excess power of } 33,059 \\
\mathrm{kWh} / \text { year. }\end{array}$ \\
\hline Converter & Generic & $1 \mathrm{kWh}$ & $\begin{array}{l}\text { G3: The inverter operates for } 2.122 \text { hours/year with a } \\
\text { maximum output of } 0.210 \mathrm{~kW} \text { and losses of } 8.17 \\
\mathrm{kWh} / \mathrm{year} \text {. The rectifier operates for } 893 \text { hours } / \text { year } \\
\text { with a maximum output of } 0.226 \mathrm{~kW} \text { and losses of } \\
9.55 \mathrm{kWh} / \text { year. }\end{array}$ \\
\hline Converter & Generic & $1 \mathrm{kWh}$ & $\begin{array}{l}\text { G10: The inverter operates for } 1.247 \text { hours/year with } \\
\text { a maximum output of } 0.210 \mathrm{~kW} \text { and losses of } 5.51 \\
\mathrm{kWh} / \mathrm{year} \text {. The rectifier operates for } 893 \text { hours } / \text { year } \\
\text { with a maximum output of } 0.223 \mathrm{~kW} \text { and losses of } \\
6.44 \mathrm{kWh} / \mathrm{year} \text {. }\end{array}$ \\
\hline
\end{tabular}

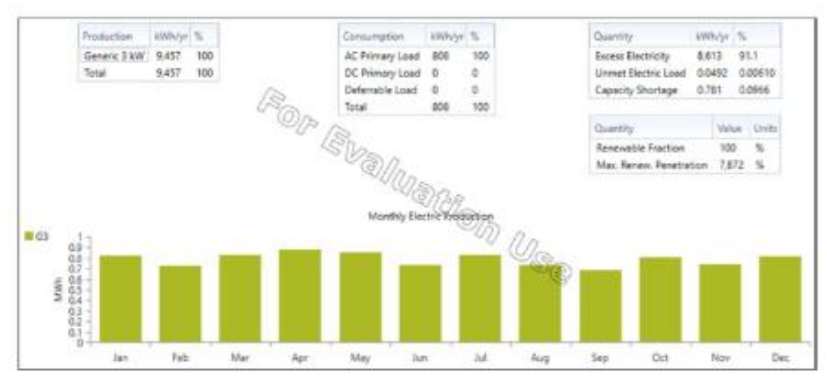

Figure 12 Typical monthly average electric production of G3

The simulation mechanism of HOMER is a loadfollowing system that meets the main load requirement in advance and other sales against any excess power. Based on simulation results using the two wind turbines, it can be analyzed that each wind turbine has a designation or use in a particular sector and region or scale. G3 wind turbines tend to be more suitable for small-scale use such as small areas. In larger areas, a G10 wind turbine can be used. Apart from the consideration of the expensive cost, the average wind speed of $7.07 \mathrm{~m} / \mathrm{s}$ is still classified a low, especially for the G10 wind turbine.

For the validation, it is reported that Ketapang Regency has the highest wind speed compared with others, produced electric power of $1.013 \mathrm{~kW}$ [15]. In general, wind speed in Indonesia is categorized into the $3^{\text {rd }}$ category [16], i.e. $4.5-12 \mathrm{~m} / \mathrm{s}$, that produced electric energy of more than $1000 \mathrm{kWh} /$ year. These articles validated the present study.

\section{IV.CONCLUSION}

The present study concludes that the wind power potential in this study is based on the normal 
meteorological standard. Wind power potential was low in June and December, however, it has the highest value in April. The northern and southern coasts of West Kalimantan (Sambas and Ketapang Regency) had higher wind power potential than other areas in West Kalimantan, i.e. $>26 \mathrm{~W} / \mathrm{m}^{2}$. The highest wind power potential was documented in Ketapang Regency (Tumbang Titi Subdistrict), which reached $>52 \mathrm{~W} / \mathrm{m}^{2}$. Wind power potential capability shows that a wind power plant should be built in Tumbang Titi Sub-district. Based on monthly average production, the $\mathrm{G} 3$ turbine produced the monthly average electricity production $9,457 \mathrm{kWh} /$ year. The main (primary) loads had been fulfilled $808 \mathrm{kWh} /$ year and excess power of $8,613 \mathrm{kWh} /$ year. Meanwhile, if a G10 wind turbine is used, it can produce $33,892 \mathrm{kWh} /$ year of electricity, the primary load has been fulfilled $808 \mathrm{kWh} /$ year and has excess power of 33,059 $\mathrm{kWh} /$ year.

\section{REFERENCE}

[1] Ministry of Energy and Mineral Resources, "Decision of the Minister of Energy and Mineral Resources of the Republic of Indonesia", No. 5899.K/20/MEM/2016 on Ratification of Electrical Power Provision Effort Plan of PT. PLN (Persero) from 2016 to 2025, 2016.

[2] Presidential Decree of the Republic of Indonesia Number 61, "National Greenhouse Gas Emission Reduction Action Plan", 2011.

[3] Directorate General of New Renewable Energy and Energy Conservation of the Ministry of ESDM (Ditjen EBTKE), "New Energy and Renewable Energy Potentials in Indonesia Outlook Energy 2009", Jakarta: National Board of Energy, 2018.

[4] U.Z. Adlina, A. Ihwan, and Apriansyah, "Potensi Energi Listrik Tenaga Angin di Kota Pontianak", Vol. VI (01), Prisma Fisika, pp.22-25, 2018.
[5] K. E. Bawan, "Kajian Potensi Energi Angin Kabupaten Kaimana Provinsi Papua Barat”, Vol. 6 (2), Natural, 2007, pp. 69-73.

[6] A. Sam and D. Patabang, "Studi Potensi Energi Angin di Kota Palu untuk Membangkitkan Energi Listrik", Vol. 3 (1), Jurnal SMARTek, pp. 21-26, 2005.

[7] GIS (Geographic Information System) Geography 2000, "Inverse Distance Weighting”, Available: http://gisgeographyy.com/

[8] World Meteorological Organization, "WMO Guideline on the Calculation of Climate Normal", Geneva: World Meteorological Organization, 2017.

[9] World Meteorological Organization (WMO-TD/No.341), "Calculation of Monthly and Annual 30 -Year Standard Normal", Washington, DC: World Climate Programmed Data, 1989.

[10] Y. F. Kusuma and Sulistya, "Pengukuran Kecepatan Angin di Dalam dan di Sekitar Model Stasiun Menggunakan Constant Temperature Anemometer", Journal of Aero Technology, Vol. 1 (2), pp. 19-27, 2018

[11] V. P. Chauhan, "Additive versus Multiplicative Precorection of Diary Records for Some Environmental Effect in Site Evaluation", Journal of Dairy Science, Vol. 71, pp. 195-203, 1988.

[12] C. K. Brown and D. F. Warne, "An Analysis Potential for Wind Energy Production in North-Western Ontario in Wind Power Report", Canada: Ontario Research Foundation, 1981.

[13] F. Z. Setiawati, F. Aditya, and N. Hidayanto, "Pembuatan Faktor Koreksi Data NCEP/NOAA dengan Data Observasi untuk Mengisi Data Kosong”, Megasains, Vol. 10 (2), pp. 9-15, 2019.

[14] Air Force Weather Agency Training Division, "Air Force Weather Qualification Training Package: Analysis and Prognosis Trainee Workbook", Nebraska: Air Force Base, 2000.

[15] Ryski, "Kajian Kelayakan Potensi Energi Angin Pada Kawasan Universitas Tanjungpura Pontianak Untuk Dimanfaatkan Menjadi Energi Listrik", Jurnal Teknik Elektro Untan, Vol. 1, No.1, 2013.

[16] R. U. Irene, Muh. Ishak Jumarang, and Apriansyah, "Perhitungan Potensi Energi Angin di Kalimantan Barat", Prisma Fisika, Vol. VI, No. 01, pp. 65-69, 2018 